\title{
Talent Management Dalam Meningkatkan Kinerja Lembaga KSPPS BMT Mitra Sadaya Cabang Purwakarta
}

\author{
Jalaludin ${ }^{1}$, Heru Komarujaman ${ }^{2 *}$ \\ 1,2 Program Studi Ekonomi Syariah Konsentrasi Manajemen Syariah \\ Program Pascasarjana UIN Sunan Gunung Djati Bandung \\ 1 jalaludin.uinsgd@yandex.com \\ 2*her.komarujaman@gmail.com
}

\begin{abstract}
Adaptation companies to pass talent management need at global era in view of information current and fast change and then continuous.Human resources with new talent for organization is need to achieve organization success/performance. Organization must time increase and energy to repair performance from new talent. Talent will compete do the best for organization when organization will appreciate the job.
\end{abstract}

Keywords : Talent Management, Organization Performance

Abstrak - Era Global mengharuskan perusahaan atau lembaga keuangan beradaptasi melalui talent management. Mengingat arus informasi dan perubahan yang cepat dan terus menerus tidak bisa dihentikan seperti banyak munculnya uang digital. Sumber daya insan dengan talenta baru dan kreatif bagi lembaga keuangan diperlukan untuk mencapai keberhasilan kinerja lembaga keuangan khususnya pada KSPPS BMT Mitra Sadaya cabang Purwakarta. Lembaga keuangan harus menambah waktu, tenaga dan pikiran untuk memperbaiki kinerja dari talenta baru tersebut. Para talent akan berlomba-lomba untuk melakukan yang terbaik bagi lembaga keuangan apabila lembaga keuangan syariah menghargai pekerjaannya.

Kata kunci : Talent Management, Kinerja lembaga keuangan.

\section{Pendahuluan}

Keberadaan karyawan disuatu lembaga keuangan mutlak dibutuhkan untuk mencapai keberhasilan tujuan yang ingin dicapai. Lembaga keuangan yang mempunyai karyawan dengan talent yang sesuai dengan kebutuhan lembaga keuangan akan membuat lembaga lebih kompetitif. Dengan mempertahankan orang-orang yang memiliki talenta tinggi menjadi sangat penting. Hal ini dikenal sebagai talent management (manajemen bakat).

Capelli (2009; dalam Andry 2011) berpendapat bahwa: "Talent management berkaitan dengan mencari orang yang tepat dengan keterampilan yang tepat untuk posisi yang tepat." semakin besarnya kesadaran perusahaan-perusahaan akan talent tersebut, maka dewasa ini mereka bersaing untuk mendapatkan karyawan yang bertalenta tinggi, baik dengan cara mencari dari luar maupun dari pelatihan dan kaderisasi. Kekurangan talent merupakan hal serius bagi pertumbuhan lembaga di masa depan. Seperti halnya di KSPPS BMT Mitra Sadaya Cabang Purwakarta membutuhkan karyawan yang bertalenta tinggi, karena proses funding dan landing dalam lembaga KSPPS BMT Mitra Sadaya cabang Purwakarta berbeda dengan praktek yang dilakukan oleh perbankan. Dengan demikian perekrutan setiap individu yang memiliki keterampilan berbeda-beda menjadi sangat penting. Tugas yang cukup sulit bagi lembaga keuangan adalah mengidentifikasi individu yang cocok dengan budaya organisasi atau lembaga keuangan yang ada. Hal ini dilakukan dengan mempelajari dan mengevaluasi setiap individu pada kemampuan, bakat, kepribadian, dan karakter mereka. Dalam kaitannya dengan mengisi kekosongan jabatan tertentu dalam lembaga keuangan. Prosedur pemilihan sumber daya insani yang efektif akan mampu untuk mengidentifikasi keahlian pegawai atau karyawan dengan tepat. Bila berhasil mendapatkan individu-inidividu yang lebih baik dari pesaing, maka akan didapatkan lembaga yang lebih baik dari pesaing lainnya.

Talent management tidak akan berhasil jika tidak ada sistem seleksi, yang salah satunya adalah sistem untuk mengidentifikasikan hasil kinerja. Jika seorang pegawai memiliki kinerja yang dianggap rata-rata maka mereka harus dihargai atas kinerjanya, sedangkan yang berprestasi di lembaga atau perusahaan harus menerima imbalan yang lebih tinggi untuk menjaga motivasinya.

\section{METODOLOGI}

Ditinjau dari jenis datanya pendekatan penelitian yang digunakan dalam penelitian ini adalah pendekatan kualitatif. Adapun yang dimaksud dengan penelitian kualitatif yaitu penelitian yang bermaksud untuk memahami fenomena 
tentang apa yang dialami oleh subjek penelitian secara holistik, dan dengan cara deskripsi dalam bentuk kata-kata dan bahasa, pada suatu konteks khusus yang alamiah dan dengan memanfaatkan berbagai metode ilmiah (Moleong, 2007:6). Adapun jenis pendekatan penelitian ini adalah deskriptif. Penelitian deskriptif yaitu penelitian yang berusaha untuk menuturkan pemecahan masalah yang ada sekarang berdasarkan data-data. Jenis penelitian deskriptif kualitatif yang digunakan pada penelitian ini dimaksudkan untuk memperoleh informasi mengenai talent management dalam meningkat kinerja karyawan pada lembaga KSPPS BMT MItra Sadaya cabang Purwakarta.

Obyek penelitian dapat dinyatakan sebagai situasi sosial penelitian yang ingin diketahui apa yang terjadi di dalamnya. Pada obyek penelitian ini, peneliti dapat mengamati secara mendalam aktivitas (activity) orang-orang (actors) yang ada pada tempat (place) tertentu (Sugiyono, 2007:215). Obyek dari penelitian ini adalah talent management dalam meningkat kinerja karyawan pada lembaga KSPPS bait al-Maal wa alTamwil (BMT) Mitra sadaya cabang Purwakarta.

Subjek penelitian merupakan sumber data yang dimintai informasinya sesuai dengan masalah penelitian. Adapun yang dimaksud sumber data dalam penelitian adalah subjek dari mana data diperoleh (Suharsimi Arikunto, 2002:107). Untuk mendapat data yang tepat maka perlu ditentukan informan yang memiliki kompetensi dan sesuai dengan kebutuhan data (purposive). Penelitian ini bertujuan untuk mengetahui ciriciri karyawan bertalenta, proses perekrutan karyawan atau pegawai, dan pengembangan bakat talenta karyawan atau pegawai pada lembaga KSPPS BMT Mitra Sadaya cabang Purwakarta. Oleh karena itu, diperlukan subjek yang memenuhi parameter yang dapat mengungkap hal di atas sehingga memungkinkan data dapat diperoleh. Parameternya adalah sebagai berikut:

1. Mengetahui tentang talent management.

2. Terlibat langsung dalam proses perekrutan karyawan atau pegawai.

3. Ikut terlibat berkoordinasi dalam kaitannya dengan kegiatan talent management dalam meningkatkan kinerja karyawan.

\section{HASIL DAN PEMBAhaSAN}

\section{Definisi Talent Management}

Istilah talent management pertama kali diperkenalkan oleh McKinsey \& Company following melalui salah satu studi yang dilakukannya tahun 1997. Pada tahun berikutnya, talent management kemudian menjadi salah satu judul buku yang ditulis bersama oleh Ed Michaels, Helen Handfield-Jones, dan Beth Axelrod. Talent management atau manajemen bakat adalah suatu proses menejemen SDM terkait tiga proses. Pertama, mengembangkan dan memperkuat karyawan baru pada proses pertama kali masuk perusahaan (onboarding). Kedua, memelihara dan mengembangkan karyawan atau pegawai yang sudah ada di perusahaan. Ketiga, menarik sebanyak mungkn pegawai yang memiliki kompetensi, komitmen dan karakter bekerja pada perusahaan, Simalango (2009).
Definisi lain disampaikan oleh Groves (2007) talent management secara umum berkaitan dengan pelatihan mengenai strategi pengembangan, mengidentifikasikan talent gaps, succession planning, serta merekrut, menyeleksi, mendidik, memotivasi, dan memelihara karyawan yang memiliki talent melalui berbagai inisiatif. Perusahaanperusahaan yang menggunakan talent management sebagai salah satu strategi pengelolaan sumber daya manusia berusaha seoptimal mungkin mengaitkan proses pencarian, pemikatan, pemilihan, pelatihan, pengembangan, pemeliharaan, promosi, dan pemindahan karyawan atau pegawai agar terkait dengan bisnis utama perusahaan.

\section{Tujuan Talent Management}

Inisiatif dalam melaksanakan talent management dalam bisnis memiliki banyak tujuan. Menurut Smilansky (2008), tujuan utamanya adalah mengembangkan top management terbaik dalam menghadapi persaingan bisnis, mencari kandidat eksternal yang baik untuk mengisi pekerjaan kunci, saling mengisi talent antar unit yang berbeda, mempertahankan seorang bertalenta melalui kesempatan pengembangan karir, memperluas kelompok talent internal dengan memfokuskan pada sejumlah karyawan yang berbeda, dan membangun kebutuhan bersama untuk memiliki pemain terbaik sebagai kunci untuk keberhasilan bisnis mendatang. Demikian pula dengan KSPPS BMT Mitra Sadaya cabang Purwakarta menerapkan talent management salah satu tujuannya adalah tercapainya visi misi dari lembaga, dan tercapainya team yang komit, kompak, dan pemegang kunci kesuksesan lembaga.

\section{Ciri-Ciri Karyawan Bertalenta (Talent People)}

Menurut Shahindra (2007), karyawan bertalenta (talent people) dapat diamati atau perhatikan dari sikap dan perilakunya. Berikut disajikan sikap atau perilaku karyawan bertalenta :

a. Karyawan bertalenta membuat dan merumuskan aturan (breaking the rule). Karyawan dengan talenta tinggi tidak segan-segan untuk membuat dan merumuskan aturan yang mampu meningkatkan kinerja.

b. Karyawan bertalenta memulai dan membuat perubahan.

c. Karyawan bertalenta selalu menciptakan kreatifitas.

d. Karyawan talenta seringkali menjadi sumber informasi yang dapat dipercaya didalam unit atau organisasinya. Mereka memberikan data, saran dan kreatif membentuk hal baru yang penting dan mengubah ke arah yang lebih baik.

e. Karyawan bertalenta menciptakan inovasi.

f. Karyawan bertalenta mengarahkan karyawan lainnya.

g. Karyawan bertalenta memberi inspirasi dan memotivasi karyawan lainnya.

\section{Proses Talent Management}

Secara umum perusahaan atau lembaga keuangan akan melakukan sebuah proses talent management yang terdiri atas :

\section{a. Proses Rekrutmen Dan Seleksi Yang Ketat}

Ini merupakan proses awal karir sebuah talent akan memasuki sebuah perusahaan. Dengan melakukan langkah ini, perusahaan akan mendapatkan talent-talent yang berkualitas. 
Teknik menemukan dan merekrut talenta (Shahindra : 2007), Individu dengan talenta berkualitas tinggi sangatlah langka, dan kebanyakan organisasi kesulitan memperolehnya. Beberapa karakter kandidat dengan talenta yang tinggi, umumnya merupakan individu yang sangat sukses, dan tidak begitu bermotivasi untuk keluar dari posisi mereka serta juga tidak aktif mencari pekerjaan baru. Namun, hal yang sebaliknya terjadi pada kandidat berkualitas rendah. Untuk merekrut talenta terbaik. Ada beberapa langkah yang dapat dilakukan :

1) Definisikan secara jelas tingkat kebutuhan talenta yang paling dibutuhkan. Sebelum memulai pencarian, spesifikasikan kompetensi dan pengalaman minimum yang diperlukan lembaga keuangan yang paling menggambarkan talenta. Contohnya : gambarkan secara detil tipe pencapaian individu (performance achievement) yang paling sesuai dan dengan jenis perusahaan/ organisasi seperti pada KSPPS BMT Mitra Sadaya cabang Purwakarta sebelum melakukan recruitment karyawan harus diketahui job kosong dibagian mana dan kandidat yang dibutuhkan minimal berpengalaman atau tidaknya serta minimum pengetahuan atau pemahaman terhadap syariah. Dengan langkah ini, berarti kita telah menempatkan basis yang paling kuat dalam aktifitas rekruitmen untuk membantu memperoleh kandidat ideal bertalenta.

2) Uraikan kesempatan yang menantang. Jelaskan pula pencapaian yang bisa diperoleh sesuai dengan peran atau tanggungjawab pekerjaan bagi kandidat. Jangan lupa meletakkan keseimbangan antara kesempatan dan kualitas individu yang dicari. Individu bertalenta tidak akan tertarik dengan kesempatan atau tantangan yang terbatas, perusahaan yang sedang-sedang saja atau peran pekerjaan yang tidak menarik.

3) Jalinlah kemitraan dengan agensi rekrutmen yang memahami dan mengerti kebutuhan organisasi. Agensi rekrutmen yang baik akan memahami talenta apa dan bagaimana memberikan kandidat terbaik yang memenuhi harapan anda. Seperti halnya yang pernah dilakukan oleh KSPPS BMT Mitra Sadaya cabang Purwakarta yang bekerja saman dengan lembaga Rajawali Purwamitra Sukses dalam membantu perekrutan karyawan.

4) Perankan "pemasaran" dalam merekrut talenta. Dengan mengembangkan pendekatan pemasaran, kita dapat memperoleh talenta berkualitas tinggi. Kita akan mengetahui, dimana individu-individu seperti ini berada, karena sudah dijelaskan di dalam spesifikasi pekerjaan. Kita dapat menggunakan kombinasi media cetak maupun media online dan aktifitas lainnya yang menggambarkan aspek pemasaran efektif merekrut talenta. Sebaiknya tidak bergantung pada satu saluran komunikasi pemasaran, karena hanya memberikan akses terbatas terhadap kandidat bertalenta. Yang sering dilakukan oleh KSPPS BMT Mitra Sadaya cabang Purwakarta dalam mencari kandidat karyawan bertalenta melalui media online seperti facebook, Instagram, dan blackberry massager.
5) Tentukan jangka waktu penempatan. Individu bertalenta memiliki waktu terbatas, dan umumnya kehilangan perhatian jika proses perekrutan terlalu lama. Seperti halnya perekrutan hanya dibuka selama seminggu, dua minggu, tiga minggu, dan atau empat minggu.

6) Kurangi resiko. Gunakan seperangkat tools yang efektif dalam screening kandidat, gunakan teknik competency based interview dan ujilah kandidat untuk memvalidasi ketrampilan dan kompetensi yang sesuai. Langkah paling penting untuk memvalidasi semua informasi ini dan yang menjadi proses final adalah mengecek referensi secara detil. Dalam bagian ini pemahaman penulis, system perekrutan karyawan bertalenta lebih banyak dan paling banyak menggali informasi mengunakan system interview, tetapi ada beberapa data yang diperlukan melalui test tulisan, namun disarankan tidak terlalu banyak.

Dengan mengikuti langkah diatas, perekrut diharapkan akan memiliki kepercayaan tinggi terhadap semua kandidat yang telah dipilih dari kumpulan kandidat terbaik yang tersedia, sehingga organisasi atau lembaga dapat menemukan dan memperoleh individu bertalenta sesuai dengan kebutuhan dan sasaran organisasi atau lembaga.

\section{b. Pemetaan Talent}

Menemukan karyawan berbakat dalam perusahaan bukan pekerjaan mudah. Banyak lembaga keuangan, atau bagian SDI yang menggunakan assessment tools, pscyhometric atau talent questionnaire untuk menentukan karyawan yang memiliki talenta. Namun apabila cara-cara tersebut tidak disosialisasikan dengan benar, akan dapat menimbulkan respon yang kurang baik dari karyawan. Pemetaan talent dilakukan agar para talent dapat dikelompokan kedalam kompetensi dan keahliannya masing-masing. Pihak perusahaan akan dengan mudah memantau perkembangan setiap talentnya.

Identifikasi Karyawan berbakat (Shahindra 2011). Memetakkan karyawan berbakat merupakan langkah penting yang bila dilakukan secara tidak tepat malah menyia-nyiakan kapabilitas yang dimiliki karyawan tersebut. Langkah identifikasi dapat dijalankan dengan mengamati, memperhatikan dan melihat sikap maupun perilaku karyawan. Tentu saja dengan melihat dampak dari perilaku tersebut.

Bakat yang dimiliki seorang karyawan harus dipelihara, dibina dan dikembangkan. Dengan demikian karyawan berbakat tetap bermotivasi dan memiliki komitmen untuk memberikan pekerjaan dan hasil terbaik. Pemetaan bakat membantu organisasi fokus dalam sasaran jangka pendek tanpa kehilangan arahan atau gambaran besar sasaran jangka panjang. Dengan kata lain, membantu strategi organisasi jangka panjang serta menentukan bakat apa yang perlu ditambahkan untuk menjamin keberlangsungan sukses bisnis di masa depan.

Para pimpinan organisasi atau lembaga perlu dilatih bagaimana menentukan, membina dan mengembangkan bakat dan diberi insentif agar waktu yang diperlukan untuk mengelola bakat menjadi salah satu prioritas bisnis mereka. 
Ke depannya, ukuran keberhasilan para pemimpin organisasi atau lembaga adalah seberapa jauh mereka dapat menemukan karyawan berbakat di organisasi atau lembaga mereka untuk keberhasilan dan kesuksesan bisnis masa depan.

Berikut ini langkah-langkah pemetaan bakat yang dapat digunakan untuk membantu organisasi atau lembaga keuangan syariah dalam meningkatkan kinerja melalui peningkatan talent management :

1) Mengidentifikasi keterampilan, pengetahuan dan keahlian teknis yang diperlukan untuk membuat organisasi berhasil dalam iklim maupun kondisi eksternal saat ini.

2) Mencari tahu sejauh mana bakat karyawan yang ada berdasarkan langkah identifikasi yang ada serta kebutuhan fungsi organisasi, kemudian plotkan ke dalam peta bakat. Analisa kesenjangan (gap) dari segi ketrampilan, pengetahuan maupun keahlian dengan mengembangkan karyawan yang ada baik yang bisa dikembangkan dari dalam maupun dari luar.

3) Menggunakan karyawan berbakat yang ada sampai efek maksimum, termasuk didalamnya memundahkan karyawan berbakat dengan ketrampilan, keahlian atau pengetahuan khusus ke tempat atau fungsi organisasi yang paling dibutuhkan. Sebagai contoh, jika lembaga keuangan syariah memperoleh karyawan yang berbakat menulis dengan baik, tempatkan mereka atau beri fungsi tambahan di public relation untuk hubungan dengan mass media.

4) Bakat sebagai mana disebutkan diatas adalah dinamis dan perlu dikembangkan. Dengan menggunakan peta bakat, perlu dilihat agar karyawan dapat ditambahkan maupun dikembangkan dengan menyediakan sarana dan fasilitas tepat untuk hal diatas. Karena jika ditempatkan pada fasilitas yang kurang tepat maka talenta tersebut tidak bisa disalurkan dengan baik.

5) Membuat peta bakat selalu mutakhir (up-to-date) Dengan demikian gambaran akurat tentang karyawan berbakat serta keterampilan dan pengetahuan yang diperlukan masa mendatang, memungkinkan organisasi dengan cepat dan efektif beradaptasi terhadap perubahan lingkungan bisnis maupun eksternal. Untuk menjaga keberlangsungan dan keberadaan karyawan berbakat melalui Talent Management System, sebagai perangkat yang efektif untuk menciptakan hubungan yang simbiosis antara kemampuan dan organisasi guna meningkatkan kinerja secara drastis. Sistem ini merupakan fungsi yang berbeda dalam system organisasi yang ditujukan eksklusif untuk memikat, memelihara, mengelola dan mengidentifikasi karyawan berbakat. Secara umum, dijalankan oleh manajemen bersama bagian organisasi yang menjalankan fungsi sumber daya manusia.

\section{c. Talent Pool}

Talent Pool merupakan sebuah hasil saringan dari para talent terbaik di setiap kelompoknya. Para talent best of the best yang dimasukkan dalam talent pool ini akan dipromosikan guna meneruskan kepemimpinan bisnis perusahaan. Umumnya talent pool ini berisikan 3\% dari setiap populasi karyawan setiap unit.

Cara membangun Talent Pool. Banyak organisasi atau lembaga keuangan syariah berusaha menerapkan talent management yang diyakini dapat mewujudkan sukses yang berkesinambungan. Istilah talent mengandung aspek yang dikaitkan dengan evaluasi berdasarkan kesanggupan atau kompetensi seseorang. Hal penting lainnya adalah adanya prinsip pengembangan. Landasan pemikiran yang perlu dipahami dalam talent pool atau talent management berkaitan dengan tujuan strategis organisasi atau lembaga keuangan syariah untuk menjamin kesinambungan kesuksesan organisasi atau lembaga dalam jangka panjang.

Organisasi atau lembaga keuangan kemudian mengidentifikasi kemampuan apa yang penting untuk mendukung keberhasilan jangka panjang organisasi atau lembaga keuangan. Kemudian, dilihat posisi-posisi apa yang kritikal dalam organisasi atau lembaga keuangan syariah yang dituntut untuk memiliki kemampuan atau kompetensi yang penting tersebut. Posisi kritikal tersebut kemudian harus didefinisikan dengan jelas peran dan tanggung jawabnya, hasil kinerja yang diharapkan dan kompetensi yang diperlukan untuk itu semua. Dengan kata lain, posisi kritikal akan menjadi future leadership positions bagi keberhasilan organisasi atau lembaga. Setelah potret ideal yang diharapkan agar dapat sukses itu jelas didefinisikan, maka selanjutnya organisasi atau lembaga keuangan mengidentifikasi orangorang yang potensial untuk dikembangkan mengemban peran dan tanggung jawab posisi kritikal tadi. Di sinilah prinsip evaluasi kesangggupan atau kompetensi diterapkan.

Kebutuhan akan posisi-posisi kritikal dapat dibuat berjenjang untuk memastikan rantai pasokan dari suatu level ke level yang lebih tinggi dalam organisasi atau lembaga keuangan dapat berjalan lancar dan berkesinambungan, sehingga tidak akan terjadi putusnya kader pemimpin yang akan membawa keberhasilan organisasi. Pipa saluran kepemimpinan ini dapat dibuat mulai dari level entry manager atau individual contributor/specialist, middle manager atau key technical expert, key executives/directors, sampai dengan pucuk pimpinan atau CEO. Dalam proses pengembangan dan penyiapan talent tersebut, perlu juga dibuat kriteria seleksi untuk mengevaluasi secara periodik apakah sang calon masih layak berada dalam talent pool atau harus keluar. Ini untuk memelihara situasi kondusif kompetisi dan rangsangan kinerja, dan mengeliminasi calon yang kinerja dan potensinya menurun dalam perjalanan.

Proses berikutnya yang penting adalah menyusun dan menyiapkan program pengembangan khusus bagi calon pemimpin masa depan yang ada dalam talent pool tersebut. Program ini harus dirancang secara khusus, tidak hanya sekedar program pelatihan tradisional, tapi juga mencakup hal-hal praktis yang dapat secara langsung memberikan dampak peningkatan skills dan pembentukan behaviours yang diharapkan. Perlu juga diperhatikan evaluasi hasil pengembangan talent pool dengan mengukur dampak program talent management yang ada tersebut terhadap hasil akhir 
organisasi. Jikalau tidak meningkatkan hasil akhir organisasi, maka sudah pasti penerapan talent management tersebut perlu dirancang ulang agar dapat memberikan high impact bagi organisasi.

Talent pool tersebut, perusahaan melakukan proses identifikasi dan kemudian mengembangkan mereka menjadi calon suksesor tersebut. Seperti yang diungkapkan oleh Berger \& Berger (2008), "Identifikasi suksesor potensial adalah awal proses, mereka perlu diberikan kesempatan sepenuhnya untuk mengembangkan keterampilan dan menambah pengalaman yang akan mereka butuhkan ketika menjadi CEO.” Dari pendapat Berger \& Berger tersebut, jelas bahwa untuk tercapainya succession planning, perusahaan harus melaksanakan talent management untuk mengidentifikasi, melatih, dan mengembangankan calon suksesornya.

Pelatihan dan pengembangan yang diberikan perusahaan kepada calon suksesor harus sesuai dengan talent yang mereka miliki sehingga perusahaan perlu memperhatikan faktor-faktor kunci dalam menghasilkan talent management yang efektif.

\section{d. Talent Satisfaction}

Inilah faktor kunci yang akan menjadikan para talent betah bekerja di sebuah perusahaan. Program ini memberikan para talent berbagai fasilitas dan pengembangan yang meliputi:

1) Kebutuhan untuk hidup. Para talent akan diberikan sistem renumerasi pendapatan yang kompetitif dengan perusahaan lain. Berbagai fasilitas dan kemudahan dalam menyikapi beban hidup harus disediakan perusahaan atau lembaga. Pada point ini masih minim yang diberikan lembaga KSPPS BMT Mitra Sadaya cabang Purwakarta kepada perusahaan, masih terbatas untuk kalangan atau jabatan tertentu saja.

2) Kebutuhan untuk berkembang. Kebutuhan untuk mengembangkan potensi diri juga amat dibutuhkan. Oleh karena itu pengembangan karir yang jelas dan kesempatan untuk belajar yang besar amat diminati para talent. Hal ini dilakukan oleh KSPPS BMT Mitra Sadaya cabang Purwakarta melalui stadi banding dengan lembaga lain, upgrading rutin yang dilakukan oleh team pusat, dan sertifikasi keahlian sesuai dengan jobnya masing-masing.

3) Kebutuhan untuk berkontribusi. Para talent membutuhkan sebuah tantangan dan keinginan yang besar dalam memajukan perusahaan. Oleh karena itu perusahaan yang memberikan kebebasan dan kreativitas yang besar kepada para talent akan membuat mereka berlama-lama dikantor. Hal ini yang sering dilakukan oleh KSPPS BMT Mitra Sadaya cabang Purwakarta memberikan kebebasan dan kreatifitas kepada karyawannya selama tidak melanggar peraturan yang ada. Hasilnya kreatifitas cabang Purwakarta lebih unggul dibandingkan cabang lainya.

4) Kebutuhan untuk dicintai. Budaya kerja yang nyaman layaknya hidup di tengah keluarga merupakan salah satu keinginan setiap karyawan. Dengan budaya kerja yang demikian dapat menghidupkan mental para talent. Suatu kejadian yang dituturkan oleh branch manager KSPPS BMT Mitra Sadaya cabang Purwakarta di 3 tahun sebelumnya. Pernah terjadi lingkungan kerja yang seperti bukan bekerja disatu lembaga, satu atap, satu menejerial, mereka acuh terhadap keadaan team dan temannya, yang mengakibatkan lingkungan kerja menjadi tidak nyaman dan banyak tuduhan buruk serta prasangka buruk yang ujungnya mengakibatkan teamnya bubar (resign) karena ketidak nyamanan dalam lingkungan kerja.

5) Kebutuhan untuk meninggalkan warisan. Para talent akan berlomba-lomba untuk melakukan yang terbaik bagi perusahaan apabila perusahaan menghargai setiap kerja mereka. Hasil karya mereka akan terekam terus diperusahaan sampai diganti dengan yang lebih baik. Ada beberapa hal dilakukan pada point ini oleh KSPPS BMT Mitra Sadaya cabang Purwakarta kepada karyawanannya, seperti bagi mantan karyawan yang selalu menjalin silaturahim walaupun sudah bekerja ditempat lain.

\section{Strategi Mengembangkan Talent Management}

Talent management menitikberatkan perhatian kepada koordinasi dan pengelolaan berbagai talent management orang-orang dalam organisasi atau lembaga keuangan syariah. Hal ini dilakukan dengan melakukan penelitian dan evaluasi setiap keahlian individu, talent management, kepribadian dan karakter, dalam hubungannya dalam pengisian lowongan dalam perusahaan. Setiap orang memiliki keahlian yang berbeda-beda, dan bagian terberat dari perusahaan adalah untuk melakukan identifikasi mana yang sesuai dengan budaya perusahaa. Prosedur Human Resources yang efektif akan dapat mengenali hal ini dan memilih dari mereka yang paling sesuai. Talent management dalam diri karyawan melibatkan banyak elemen, mulai dari kualifikasi pendidikan dan keahlian, pengalaman sebelumnya, kekuatan, dan pelatihan tambahan yang mereka ambil, kemampuan, potensi kualitas dan motivasi, kualitas dan kepribadian. Kebanyakan perusahaan melakukan talent management dengan cara yang sama, ini dapat berbentuk apa saja dari perekrutan dan pemilihan setiap individu, terhadap penempatan mereka dalam perusahaan, pelatihan, untuk meningkatkan kinerja dan berbagai skema untuk memberikan penghargaan kepada yang berkemampuan tinggi. Seberapa jauh perusahaan terlibat dalam talent management benar-benar tergantung kepada ukuran bisnis mereka dan komitmen mereka kepada pegawai atau karyawannya dan masa depan mereka.

Perencanaan pergantian adalah resep dasar dalam strategi bisnis, yang memungkinkan untuk memberikan kemampuan kepada perusahaan dalam mengenali orang yang berkinerja tinggi sehingga perusahaan dapat merencanakan penghargaan di masa yang akan datang. Penting juga untuk dilakukan proses perekrutan, baik perekrutan dari dalam atau dari luar untuk mencari talent management baru, juga harus ada bagian karir yang jelas untuk para karyawan atau pegawai yang menginginkan perkembangan. Perlu juga dilakukan kursuskursus, upgrading yang sesuai, atau pelatihan untuk melakukan persiapan-persiapan, untuk menyiapkan mereka di 
lingkungan yang baru. Piranti perencanaan pergantian dapat membantu perusahaan dalam memfasilitasi untuk mengenali dan mengembangkan talent management masa depan dalam organisasi, meningkatkan komitmen karyawan atau pegawai, dan perkembangan karir yang jelas, dan kemudahan dalam mengetahui pergantian.

Solusi yang efektif akan memberikan penghargaan atas pencapaian dari setiap individu, apakah melakukan kinerja yang bagus atau tidak dalam melakukan tindakan mereka. Ini juga akan berguna dalam membantu mengenali siapa yang harus diberikan penghargaan. Pelatihan karyawan atau pegawai, dan kebutuhan pengembangan memerlukan promosi dan penurunan yang merupakan bagian dari semua proses dan keberhasilan solusi kinerja seharusnya dapat menangani elemen-elemen ini.

Manajemen talenta tidak akan berhasil jika tidak ada sistem yang dipergunakan untuk mengenali dengan jelas hasil kinerja karyawan. Jika seorang karyawan melakukan sesuatu lebih dari standarnya, maka mereka harus diberi penghargaan,jika tidak, mereka dapat mengalami penurunan motivasi.

Outsourcing proses perekrutan sangat menghemat uang perusahaan dan meningkatkan kandidat proses perekrutan, sebagaimana juga berguna untuk memotong biaya, dan memberikan perusahaan sesuatu yang lebih besar daripada market.

Tingkat talent yang tinggi akan mengarah pada tingkat fleksibilitas organisasional, produktivitas, dan profit yang tinggi pula. Scullion \& Collings (2010) mengemukakan hasil penelitian yang dilakukan oleh McKinsey \& Company mengenai survei kepada lebih dari 120 perusahaan dengan 12.000 orang eksekutif dan 27 perusahaan terkemuka. Survei tersebut menunjukkan bahwa mengelola talent secara baik akan mengarahkan pada kinerja perusahaan yang baik pula.

Menurut Wellins, 2010 (dalam Andry 2011), ada delapan komponen kunci untuk menghasilkan talent management yang efektif, yaitu: (1) strategi bisnis, (2) talent gap, (3) perekrutan dan promosi, (4) tujuan, (5) kinerja, (6) fokus, dan (7) feedback. Dengan memiliki sekumpulan karyawan yang siap untuk dijadikan suksesor pada talent pool, perusahaan hanya perlu mencocokkan dengan waktu akan kebutuhan pergantian jabatan. Ketika waktu itu tiba, para calon suksesor tersebut tidak akan kesulitan beradaptasi dengan jabatan baru mereka. Sehingga hal ini akan berimbas kepada kinerja perusahaan yang mereka pimpin.

\section{KESIMPULAN}

Talent management yang efektif merupakan sesuatu yang krusial dalam persaingan bisnis. Hal ini dikarenakan SDI merupakan salah satu keunggulan kompetitif bagi setiap perusahaan, termasuk KSPPS BMT Mitra Sadaya cabang Purwakarta mendambakan karyawan yang muliti talenta. Dengan program talent management diharapkan perusahaan dapat menemukan dan meningkatkan bakat-bakat dan keterampilan tenaga kerja sebagai salah satu sarana utama agar mereka tetap kompetitif. Tantangan paling utama pada talent management adalah untuk menemukan, menarik, membangun dan memelihara talent tersebut.

\section{UCAPAN TERIMA KASIH}

Alhamdulillah dengan izin Allah SWT dan Hidayah-Nya, bahagia yang tak terhingga yang dirasakan penulis atas selesainya jurnal ini. Penulis sadar selesainya jurnal ini tidak terlepas dari bantuan, bimbingan, do'a dan arahan dari berbagai pihak. Untuk itu sudah selayaknya penulis dengan segala kerendahan hati ingin menyampaikan terimakasih yang mendalam dan rasa hormat kepada : Allah SWT, yang telah memberikan rahmat-Nya sehingga penulis dapat menyelesaikan jurnal ini; Ibunda dan ayahanda tercinta, yang sudah memberikan seluruh perhatian, do'a, motivasi dan kesabarannya; Istri dan anakku tercinta, yang selalu menemani penulis dan memberikan perhatian, motivasi serta kesabarannya dalam menyelesaikan jurnal ini; Segenap managerial KSPPS BMT Mitra Sadaya cabang Kabupaten Purwakarta beserta jajaran karyawan yang telah banyak membantu dalam mencari data untuk keperluan jurnal ini.

\section{REFERENSI}

A. Karnik, "Performance of TCP congestion control with rate feedback: TCP/ABR and rate adaptive TCP/IP," $\mathrm{M}$. Eng. thesis, Indian Institute of Science, Bangalore, India, Jan. 1999.

Arikunto, Suharsimi. 2002. Prosedur Penelitian Suatu Pendekatan Praktek. Edisi V Revisi. PT. Rineka Cipta. Jakarta.

Baridwan, Zaki. (2009). Sistem Akuntansi: Penyusunan Prosedur dan Metode, Edisi Kelima, Badan Penerbitan Fakultas Ekonomi, Yogyakarta.

FLEXChip Signal Processor (MC68175/D), Motorola, 1996. "PDCA12-70 data sheet," Opto Speed SA, Mezzovico, Switzerland.

J. Breckling, Ed., The Analysis of Directional Time Series: Applications to Wind Speed and Direction, ser. Lecture Notes in Statistics. Berlin, Germany: Springer, 1989, vol. 61 .

J. Padhye, V. Firoiu, and D. Towsley, "A stochastic model of TCP Reno congestion avoidance and control," Univ. of Massachusetts, Amherst, MA, CMPSCI Tech. Rep. 9902, 1999.

M. Shell. (2002) IEEEtran homepage on CTAN. [Online]. Available: http://www.ctan.org/texarchive/macros/latex/contrib/supported/IEEEtran/

M. Wegmuller, J. P. von der Weid, P. Oberson, and N. Gisin, "High resolution fiber distributed measurements with coherent OFDR," in Proc. ECOC'00, 2000, paper 11.3.4, p. 109.

Moleong, Lexy. (2013). Metodologi Penelitian Kualitatif. Bandung. PT Remaja Rosdakarya.

R. E. Sorace, V. S. Reinhardt, and S. A. Vaughn, "High-speed digital-to-RF converter," U.S. Patent 5668 842, Sept. 16, 1997.

S. M. Metev and V. P. Veiko, Laser Assisted Microtechnology, 2nd ed., R. M. Osgood, Jr., Ed. Berlin, Germany: Springer-Verlag, 1998.

S. Zhang, C. Zhu, J. K. O. Sin, and P. K. T. Mok, "A novel ultrathin elevated channel low-temperature poly-Si 

TFT," IEEE Electron Device Lett., vol. 20, pp. 569- The
571, Nov. 1999.

Sugiyono. (2007). "Metode Penelitian Kuantitatif Kualitatif dan $R \& D$ ”. Bandung: Alfabeta.
IEEE website. [Online]. Available: http://www.ieee.org/(2002)

Wiradi. 2006. Analisis Sosial. Bandung: Yayasan AKATIGA. Wireless LAN Medium Access Control (MAC) and Physical Layer (PHY) Specification, IEEE Std. 802.11, 1997. 